\title{
Effect of Organic and Inorganic Corrosion Inhibitors on Strength Properties of Concrete
}

\author{
${ }^{1} V$ Srinivasa Reddy, ${ }^{2}$ Thoodi Prashanth, ${ }^{3} S$ P Raju V, ${ }^{4} P$ Prashanth \\ ${ }^{1}$ Professor of Civil Engineering, GRIET, Hyderabad, India. \\ ${ }^{2}$ M.Tech (Structural Engineering), Department of Civil Engineering, Hyderabad, India. \\ ${ }^{3}$ Assistant Professor of Civil Engineering, GRIET, Hyderabad, India. \\ ${ }^{4}$ B.Tech Student of Civil Engineering, GRIET, Hyderabad, India.
}

\begin{abstract}
In the current study, the M25 grade concrete mixes are admixed with various locally available organic and non-organic corrosion inhibitors such as Calcium Nitrite, Sodium Nitrite, Hexamine and Di-ethanolamine to understand the influence of these organic and non-organic corrosion inhibitors on the strength and corrosion resistance properties of concrete. The percentage dosage of admixed inhibitors vary from 1 to $5 \%$ by the weight of cement. For M25 grade concrete the optimum percentages of corrosion inhibitor admixture was found to be 4\% for Calcium Nitrite, 3\% for Sodium Nitrite, 2\% for Hexamine and 3\% for Di-ethanolamine. Calcium Nitrite corrosion inhibitor admixture imparts increased compressive, split- tensile and flexural strength than other corrosion inhibitors at 28 days. All the corrosion inhibitors used in the study have enhanced the compressive strength, split tensile strength, and flexural strength of concrete. The initial gain of early strength decreased due to anodic process of inhibitors. Measured electrical resistivity and half-cell potential values of all corrosion inhibitors admixed M25 grade concrete mixes directs that calcium nitrate and Di-ethanolamine have shown high electrical resistance indicating their superior corrosion inhibition ability than sodium nitrite and hexamine. Accelerated corrosion test on reinforced concrete beams admixed with corrosion inhibitors confirmed that possible inception of corrosion in calcium nitrate admixed reinforced concrete beams is very low when compared to other corrosion inhibitors used for the study.
\end{abstract}

\section{Introduction}

The most commonly adopted approaches to enhance the service life of rebars in concrete structures are epoxy or zinc coating on the rebars, applying waterproofing agents, controlling the water/cement ratio, increasing the concrete cover thickness, application of chemical coats, cathodic protection etc [1]. However IS Code propose usage of various supplementary cementitious materials in the form of mineral admixtures provides a good solution for prevention of rebar corrosion, but whenever cracks appear in concrete rebars are exposed to corrosion. The most cost-effective and newly used practices to defer the corrosion of rebars in concrete is the usage of corrosion inhibiting admixtures in concrete [2]. Most sustainable organic inhibitors are green plant extracts which are not toxic, ecologically biodegradable, absence of heavy metals, environmentfriendly and are natural. It is hypothesized that the corrosion inhibiting admixtures not only delays the onset of corrosion but also impacts the other important properties of concrete [3]. There are various corrosion inhibitors that are in usage in the market [4]. The mechanism of corrosion in usually governed by aspects such as ingress of chloride ions and $\mathrm{H}^{+}$ ions (in acid) [5]. The corrosion inhibitive properties can be appraised in the laboratory using accelerated corrosion test based on impressed voltage technique in saline medium and supplemented by electrical resistivity and half-cell potential measurements [6].

\section{Mechanism of Inhibitors}

Corrosion inhibitors forms shielding hydrophobic film on the rebar surface in high alkalinity concrete environment by adsorbing the ions of inhibitors on to the surface which eventually delays the rate of corrosion by obstructive cathodic /or anodic reactions [7]. More technically, inhibitors forms coordinate bonds by contributing electrons to available d-orbitals of iron atoms and ultimately encouraging the adsorption of anti-oxidant molecules on the surface of rebar developing a protective layer around rebars inhibiting electrochemical process reactions such as anodic process (iron oxidation) and cathodic process(oxygen reduction) [8]. The success of inhibitors is governed by primarily the molarity or the concentration of inhibitor used. 
Higher the molarity more will be corrosion inhibiting effect $[9,10]$.

\section{Corrosion Inhibitors used for the present study}

For this present study two inorganic and two organic corrosion inhibitors were considered. They are:

\begin{tabular}{cc}
\hline Corrosion Inhibitors & Type \\
\hline $0.05 \mathrm{M} \mathrm{Calcium} \mathrm{Nitrite}$ & Inorganic \\
{$\left[\mathrm{Ca}\left(\mathrm{NO}_{2}\right)_{2}\right]$} & \\
$0.05 \mathrm{M}$ Sodium Nitrite & Inorganic \\
{$\left[\mathrm{NaNO}_{2}\right]$} & Organic \\
Hexamine $\left[\mathrm{C}_{6} \mathrm{H}_{12} \mathrm{~N}_{4}\right]$ & Organic \\
Diethanolamine $\left[\mathrm{C}_{4} \mathrm{H}_{11} \mathrm{NO}_{2}\right]$ & \\
\hline
\end{tabular}

\section{Mix Proportion}

In this section, the materials used for the present study with their proportions for M25 grade concrete mix are detailed. Ordinary Portland cement of 53 grade conforming to IS: 8112-1989 was used and physical tests were conducted as per IS: 4031. Clean locally available river sand of Zone-II is used as fine aggregate whose properties conform to IS 383-1970. Locally available well graded granite aggregates of maximum size $20 \mathrm{~mm}$ and $12 \mathrm{~mm}$ sized aggregates are used as coarse aggregates. In the present study no chemical admixtures in the form of super-plasticizers are used to minimize the effect of any other chemicals in the evaluation on impact of corrosion inhibitors.

For the present study M25 grade concrete is chosen to assess the impact of corrosion inhibitors on the properties of concrete. The mix proportions were arrived based on the BIS method of design. The materials required per $1 \mathrm{~m}^{3}$ of concrete are-

\begin{tabular}{ccccc}
\hline $\begin{array}{c}\text { Grade of } \\
\text { Concrete }\end{array}$ & Cement & $\begin{array}{c}\text { Fine } \\
\text { Aggregate }\end{array}$ & $\begin{array}{c}\text { Coarse } \\
\text { Aggregate }\end{array}$ & Water \\
\hline \multirow{2}{*}{ M25 } & $\begin{array}{c}390.12 \\
\mathrm{~kg}\end{array}$ & $\begin{array}{c}917.08 \\
\mathrm{~kg}\end{array}$ & $\begin{array}{c}703.28 \\
\text { ' } \mathrm{kg}\end{array}$ & $\begin{array}{c}224.47 \\
\text { litres }\end{array}$ \\
\hline
\end{tabular}

\section{Objectives}

1. To determine the dosage of various corrosion inhibitors

2. To evaluate the compressive, split-tensile and flexural strength of optimally admixed corrosion inhibitor based M25 concrete mixes.

\section{Methodology}

\subsection{Strength Properties}

The compressive strength properties of M25 grade concrete mix admixed with various corrosion inhibitors are determined on casted cube specimens of size $150 \mathrm{~mm}$ and testing at 3, 7, 14 and 28 days of curing as per IS: 516-1959. Likewise the split-tensile strength of casted cylindrical concrete specimens of size $150 \mathrm{~mm}$ x $300 \mathrm{~mm}$ and flexural property of casted concrete prisms of size $100 \mathrm{~mm}$ x $100 \mathrm{~mm}$ $\mathrm{x} 500 \mathrm{~mm}$ were found by testing as per IS: $516-1959$ at 3, 7, 14 and 28 days of curing.

\section{Test Results and Discussions}

Based on the experimental investigations, the test results are presented as follows-

\subsection{Compressive Strength}

The table 3 and Fig. 8 displays the compressive strengths of M25 concrete made with calcium nitrite.

Table1. Compressive strength of M25 Concrete made with calcium nitrite

\begin{tabular}{|c|c|c|c|c|}
\hline $\begin{array}{l}\text { Percenta } \\
\text { ge of } \\
\text { Calcium } \\
\text { Nitrite }\end{array}$ & $\begin{array}{l}\text { Compress } \\
\text { ive } \\
\text { strength } \\
\text { at } \\
3 \text { days } \\
\text { (MPa) } \\
\end{array}$ & $\begin{array}{c}\text { Compress } \\
\text { ive } \\
\text { strength } \\
\text { at } \\
7 \text { days } \\
\text { (MPa) } \\
\end{array}$ & $\begin{array}{l}\text { Compress } \\
\text { ive } \\
\text { strength } \\
\text { at } \\
14 \text { days } \\
\text { (MPa) }\end{array}$ & $\begin{array}{c}\text { Compress } \\
\text { ive } \\
\text { strength } \\
\text { at } \\
28 \text { days } \\
\text { (MPa) } \\
\end{array}$ \\
\hline 0 & 18.54 & 19.57 & 20.6 & 31.93 \\
\hline 1 & 12.36 & 19.57 & 25.75 & 35.02 \\
\hline 2 & 15.45 & 19.57 & 26.78 & 36.05 \\
\hline 3 & 16.48 & 20.6 & 27.81 & 37.08 \\
\hline 4 & 18.54 & 22.66 & 28.84 & 39.14 \\
\hline 5 & 17.51 & 20.6 & 25.75 & 37.08 \\
\hline
\end{tabular}

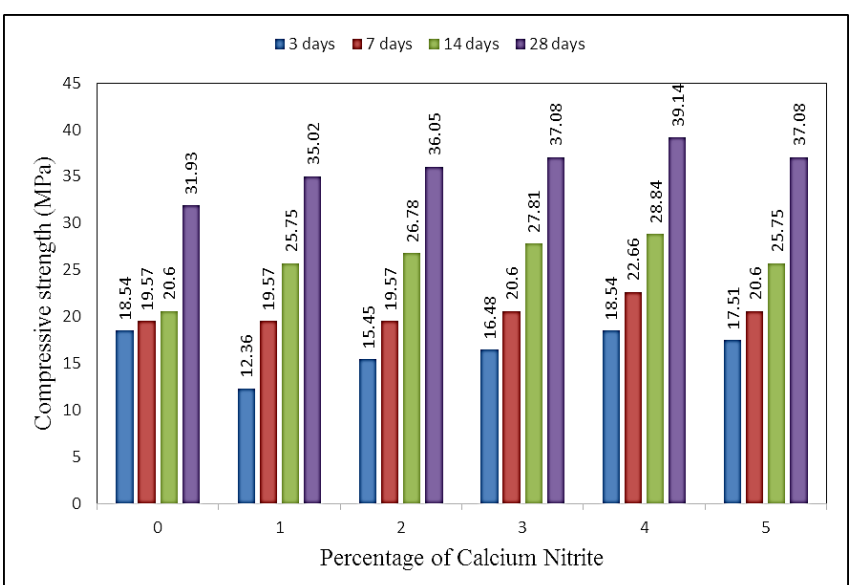

Fig. 8 - Compressive strength of M25 Concrete made with calcium nitrite

From the Table 3 and Fig. 8, it was observed that out of five different dosages of calcium nitrite by the weight of cement, $4 \%$ dosage of calcium nitrite records maximum compressive strength at 28 days. It is very evident that the gain of compressive strength in corrosion inhibitor admixed M25 concrete mix at 3 days is very slow when compared to normal concrete mix due to anodic process. Once the oxide passive layer is formed over the rebar due to anodic process of inhibitor admixture, the gain of strength improved. The improvement of compressive strength at 28 days due to $4 \%$ dosage of calcium nitrate is $22.58 \%$ over conventional concrete's compressive strength.

The table 4 displays the compressive strengths of M25 concrete made with Sodium nitrite. 
Table 4 - Compressive strength of M25 Concrete made with Sodium nitrite

\begin{tabular}{|c|c|c|c|c|}
\hline $\begin{array}{l}\text { Percent } \\
\text { age of } \\
\text { Sodium } \\
\text { Nitrite }\end{array}$ & $\begin{array}{c}\text { Compres } \\
\text { sive } \\
\text { strength } \\
\text { at } \\
3 \text { days } \\
(\mathrm{MPa}) \\
\end{array}$ & $\begin{array}{l}\text { Compres } \\
\text { sive } \\
\text { strength } \\
\text { at } \\
7 \text { days } \\
(\mathrm{MPa}) \\
\end{array}$ & $\begin{array}{l}\text { Compres } \\
\text { sive } \\
\text { strength } \\
\text { at } \\
14 \text { days } \\
(\mathrm{MPa}) \\
\end{array}$ & $\begin{array}{c}\text { Compres } \\
\text { sive } \\
\text { strength } \\
\text { at } \\
28 \text { days } \\
(\mathrm{MPa}) \\
\end{array}$ \\
\hline 0 & 17.51 & 19.57 & 21.63 & 31.93 \\
\hline 1 & 15.45 & 17.51 & 23.69 & 32.96 \\
\hline 2 & 16.48 & 18.54 & 23.69 & 33.99 \\
\hline 3 & 17.51 & 19.57 & 25.75 & 35.02 \\
\hline 4 & 15.45 & 17.51 & 23.69 & 29.87 \\
\hline 5 & 14.42 & 16.48 & 22.66 & 27.81 \\
\hline
\end{tabular}

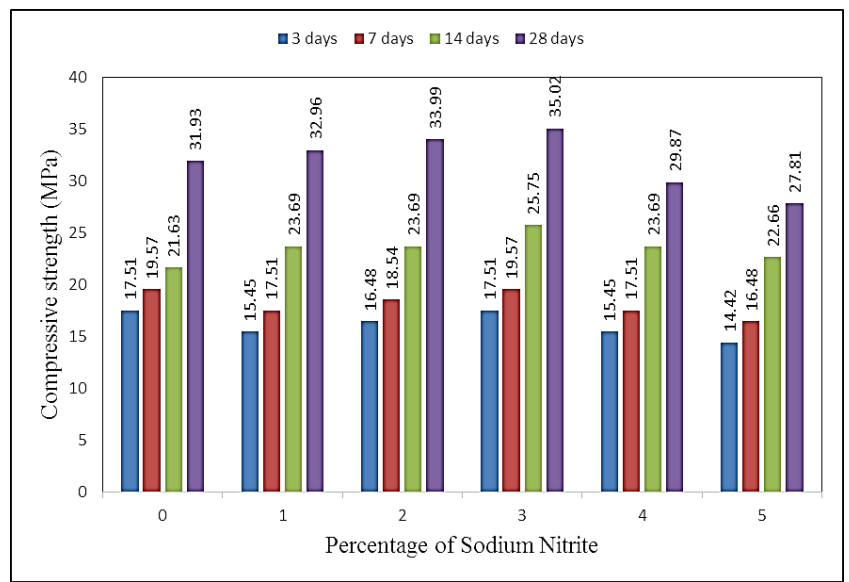

Fig. 9 - Compressive strength of M25 Concrete made with Sodium nitrite

From the test results, it was observed that out of five different dosages of sodium nitrite by the weight of cement, $3 \%$ dosage of sodium nitrite records maximum compressive strength at 28 days. It is very evident that the gain of compressive strength in corrosion inhibitor admixed M25 concrete mix at 3 days is very slow when compared to normal concrete mix due to anodic process. Once the oxide passive layer is formed over the rebar due to anodic process of inhibitor admixture, the gain of strength improved. The improvement of compressive strength at 28 days due to $3 \%$ dosage of sodium nitrate is $9.7 \%$ over conventional concrete's compressive strength. The table 5 displays the compressive strengths of M25 concrete made with Hexamine.

Table 5 - Compressive strength of M25 Concrete made with

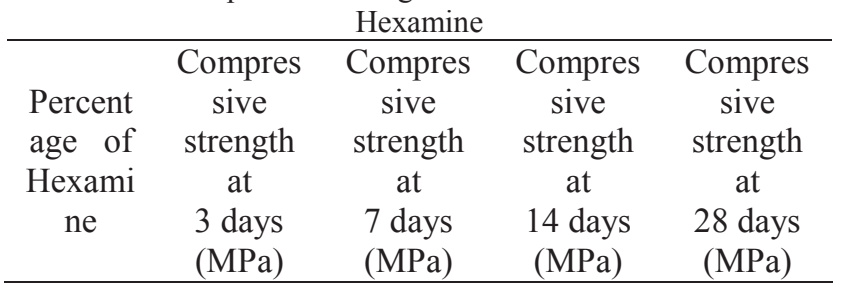

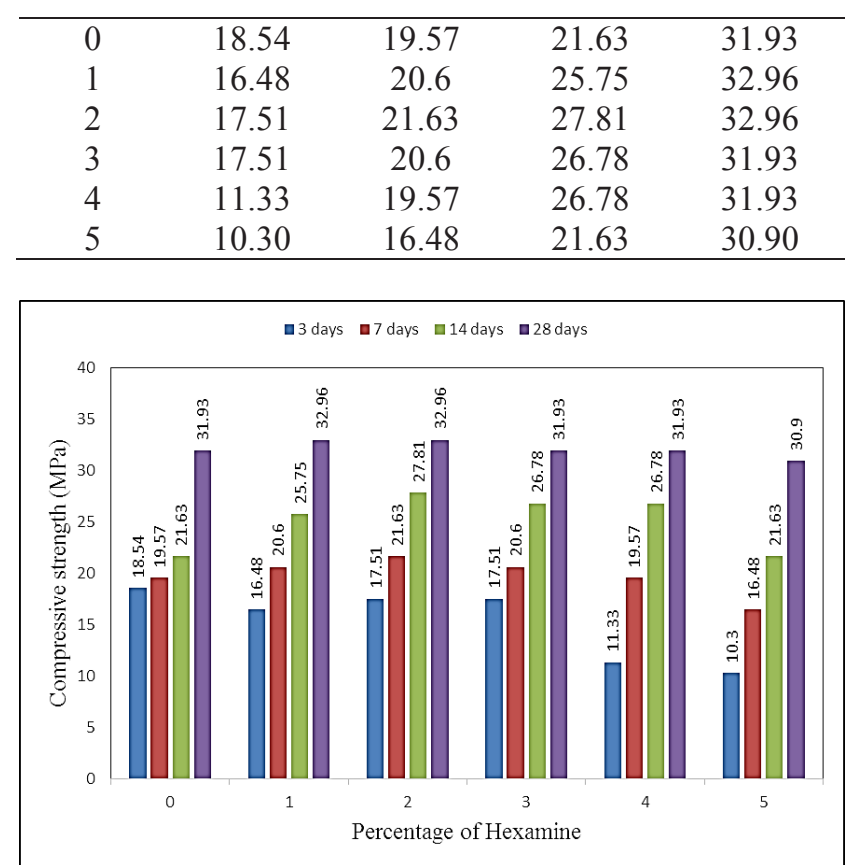

Fig. 10 - Compressive strength of M25 Concrete made with hexamine

From the test results, it was observed that out of five different dosages of hexamine by the weight of cement, $2 \%$ dosage of hexamine records maximum compressive strength at 28 days. It is very evident that the gain of compressive strength in corrosion inhibitor admixed M25 concrete mix at 3 days is very slow when compared to normal concrete mix due to anodic process. Once the oxide passive layer is formed over the rebar due to anodic process of inhibitor admixture, the gain of strength improved. The improvement of compressive strength at 28 days due to $2 \%$ dosage of Hexamine is $3.2 \%$ over conventional concrete's compressive strength

Table 6 - Compressive strength of M25 Concrete made with Di-

\begin{tabular}{|c|c|c|c|c|}
\hline $\begin{array}{l}\text { Percenta } \\
\text { ge of } \\
\text { Di- } \\
\text { ethanola } \\
\text { mine }\end{array}$ & $\begin{array}{c}\text { Compres } \\
\text { sive } \\
\text { strength } \\
\text { at } \\
3 \text { days } \\
(\mathrm{MPa})\end{array}$ & $\begin{array}{c}\text { Compres } \\
\text { sive } \\
\text { strength } \\
\text { at } \\
7 \text { days } \\
(\mathrm{MPa})\end{array}$ & $\begin{array}{l}\text { Compres } \\
\text { sive } \\
\text { strength } \\
\text { at } \\
14 \text { days } \\
(\mathrm{MPa})\end{array}$ & $\begin{array}{c}\text { Compres } \\
\text { sive } \\
\text { strength } \\
\text { at } \\
28 \text { days } \\
(\mathrm{MPa})\end{array}$ \\
\hline 0 & 12.36 & 15.45 & 21.63 & 31.93 \\
\hline 1 & 14.42 & 16.48 & 23.69 & 35.02 \\
\hline 2 & 16.48 & 17.51 & 25.75 & 35.02 \\
\hline 3 & 18.54 & 19.57 & 28.84 & 36.05 \\
\hline 4 & 14.42 & 18.54 & 23.69 & 31.93 \\
\hline 5 & 12.36 & 15.45 & 20.6 & 28.84 \\
\hline
\end{tabular}




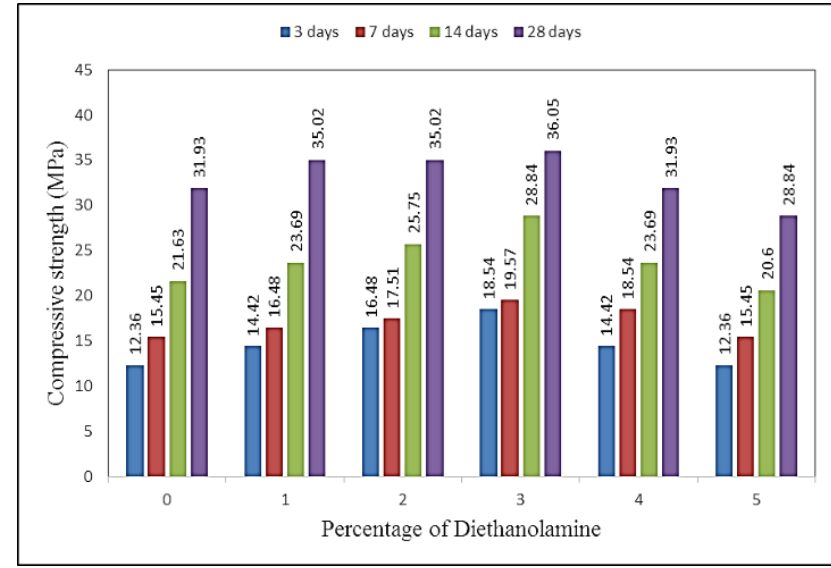

Fig. 11 - Compressive strength of M25 Concrete made with Diethanolamine

Table 7- Effect of various corrosion inhibitors on Compressive strength of M25 Concrete

\begin{tabular}{|c|c|c|c|c|c|}
\hline & \multirow[b]{2}{*}{$\begin{array}{c}\text { No } \\
\text { corros } \\
\text { ion } \\
\text { inhibi } \\
\text { tor }\end{array}$} & \multicolumn{4}{|c|}{ Corrosion Inhibitors } \\
\hline & & $\begin{array}{c}\text { Calci } \\
\text { um } \\
\text { Nitrit } \\
\mathrm{e}\end{array}$ & $\begin{array}{l}\text { Sodi } \\
\text { um } \\
\text { Nitri } \\
\text { te }\end{array}$ & $\begin{array}{l}\text { Hexa } \\
\text { mine }\end{array}$ & $\begin{array}{c}\text { Di- } \\
\text { ethanola } \\
\text { mine }\end{array}$ \\
\hline $\begin{array}{c}\text { Compres } \\
\text { sive } \\
\text { strength } \\
(\mathrm{MPa}) \\
\text { of } \mathrm{M} 25 \\
\text { Concrete }\end{array}$ & 31.93 & 39.14 & $\begin{array}{c}35.0 \\
2\end{array}$ & 32.96 & 36.05 \\
\hline $\begin{array}{c}\text { Percenta } \\
\text { ge } \\
\text { Increase }\end{array}$ & - & $\begin{array}{c}22.58 \\
\%\end{array}$ & $9.7 \%$ & $3.2 \%$ & $12.9 \%$ \\
\hline
\end{tabular}

From the test results, it was observed that out of five different dosages of Diethanolamine by the weight of cement, $3 \%$ dosage of Diethanolamine records maximum compressive strength at 28 days. It is very evident that the gain of compressive strength in corrosion inhibitor admixed M25 concrete mix at 3 days is as usual when compared to normal concrete mix. The improvement of compressive strength at 28 days due to $2 \%$ dosage of Diethanolamine is $12.9 \%$ over conventional concrete's compressive strength.

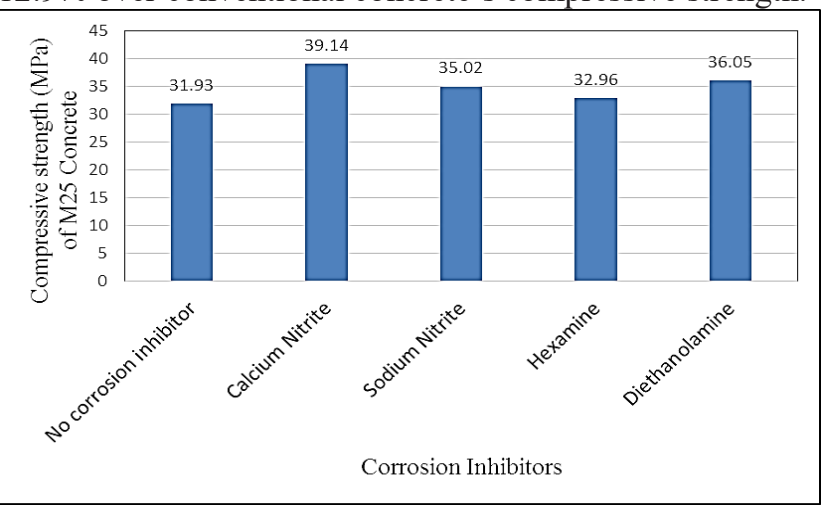

Fig. 12- Variation of Compressive strength of M25 Concrete admixed with various corrosion inhibitors at 28 days
The results evidently showed that there was no suitable correlation between the increase of the compressive strength of the concrete and type of corrosion inhibitor admixed. In inorganic inhibitors calcium nitrite fares better in compressive strength gain. Though initial gain of early strength decreased due to anodic process of inhibitors.

\subsection{Split Tensile Strength}

The table 8displays the split tensile strength of M25 concrete made with calcium nitrite.

Table 8 - Split-tensile strength (MPa) of M25 Concrete mixes admixed with various corrosion inhibitors at 28 days

\begin{tabular}{|c|c|c|c|c|}
\hline \multirow{2}{*}{$\begin{array}{c}\text { Percentag } \\
\text { e of } \\
\text { Corrosio } \\
\mathrm{n} \\
\text { Inhibitor }\end{array}$} & \multicolumn{4}{|c|}{$\begin{array}{l}\text { Split-tensile strength }(\mathrm{MPa}) \text { of } \mathrm{M} 25 \\
\text { Concrete mixes admixed with various } \\
\text { corrosion inhibitors at } 28 \text { days }\end{array}$} \\
\hline & $\begin{array}{l}\text { Calciu } \\
\mathrm{m} \\
\text { Nitrite }\end{array}$ & $\begin{array}{l}\text { Sodiu } \\
\mathrm{m} \\
\text { Nitrite }\end{array}$ & $\begin{array}{c}\text { Hexamin } \\
\mathrm{e}\end{array}$ & $\begin{array}{l}\text { Di- } \\
\text { ethanolami } \\
\text { ne }\end{array}$ \\
\hline 0 & 3.48 & 3.48 & 3.48 & 3.48 \\
\hline 1 & 3.53 & 3.51 & 3.49 & 3.51 \\
\hline 2 & 3.60 & 3.59 & 3.63 & 3.64 \\
\hline 3 & 3.75 & 3.68 & 3.59 & 3.66 \\
\hline 4 & 3.80 & 3.65 & 3.56 & 3.62 \\
\hline 5 & 3.78 & 3.63 & 3.50 & 3.59 \\
\hline
\end{tabular}

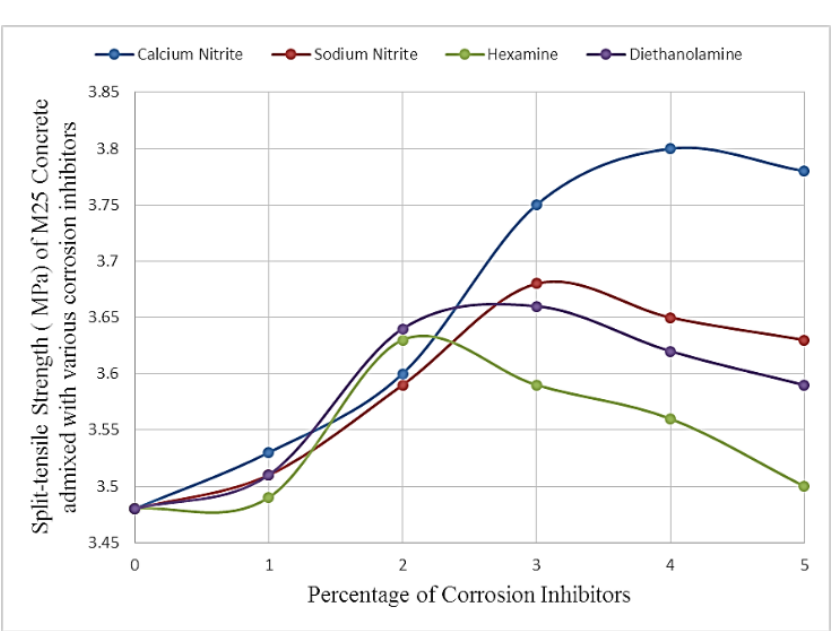

Fig. 13- Split-tensile strength of M25 Concrete mixes admixed with various corrosion inhibitors

From experimental test results, it was witnessed that $4 \%$ dosages of calcium nitrate admixture has increased the splittensile strength by $9.19 \%$ than the reference concrete. Whereas 3\% dosage of sodium nitrate admixed concrete has increased its split tensile strength by $5.75 \%$ than reference concrete as $2 \%$ hexamine admixed concrete has increased its split tensile strength by $4.31 \%$ and $3 \%$ dosage of Diethanolamine has increased its split tensile strength by $5.17 \%$. So from the various corrosion inhibiting admixtures considered for this study it was demonstrated that Calcium Nitrite contributes more to split tensile strength due to its 
more reactivity than other alkali based inhibitors. Alkali nitrates causes alkali aggregate reaction which will affect the integrity of the concrete.

\subsection{Flexural Strength}

The table 9 displays the flexural strength of M25 concrete made with calcium nitrite.

Table 9 - Flexural strength (MPa) of M25 Concrete mixes admixed with various corrosion inhibitors at 28 days

\begin{tabular}{|c|c|c|c|c|}
\hline \multirow{2}{*}{$\begin{array}{c}\text { Percentag } \\
\text { e of } \\
\text { Corrosio } \\
\mathrm{n} \\
\text { Inhibitor }\end{array}$} & \multicolumn{4}{|c|}{$\begin{array}{l}\text { Flexural strength (MPa) of M25 concrete } \\
\text { mixes admixed with various corrosion } \\
\text { inhibitors at } 28 \text { days }\end{array}$} \\
\hline & $\begin{array}{l}\text { Calciu } \\
\mathrm{m} \\
\text { Nitrite }\end{array}$ & $\begin{array}{l}\text { Sodiu } \\
\mathrm{m} \\
\text { Nitrite }\end{array}$ & $\begin{array}{c}\text { Hexamin } \\
\text { e }\end{array}$ & $\begin{array}{l}\text { Di- } \\
\text { ethanolami } \\
\text { ne }\end{array}$ \\
\hline 0 & 4.64 & 4.64 & 4.64 & 4.64 \\
\hline 1 & 5.15 & 5.15 & 5.15 & 5.15 \\
\hline 2 & 5.46 & 5.46 & 5.56 & 5.46 \\
\hline 3 & 5.76 & 5.65 & 5.46 & 5.76 \\
\hline 4 & 5.87 & 5.56 & 5.46 & 5.66 \\
\hline 5 & 5.56 & 5.25 & 4.74 & 5.36 \\
\hline
\end{tabular}

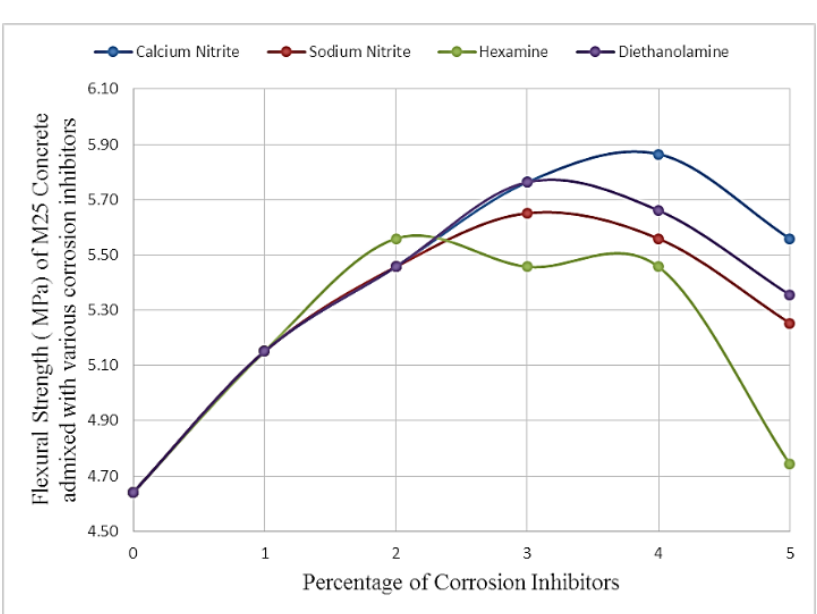

Fig. 14- Flexural strength (MPa) of M25 Concrete mixes admixed with various corrosion inhibitors (at 28 days)

From experimental test results, it was noticeably witnessed that $4 \%$ dosages of calcium nitrate admixture has increased the flexural strength by $26.51 \%$ than the reference concrete. Whereas 3\% dosage of sodium nitrate admixed concrete has increased its split tensile strength by $21.77 \%$ than reference concrete as $2 \%$ hexamine admixed concrete has increased its split tensile strength by $19.83 \%$ and $3 \%$ dosage of Diethanolamine has increased its split tensile strength by $24.14 \%$.

\section{Conclusions}

In the present study, four corrosion inhibitors admixtures such as calcium nitrite, sodium nitrite, hexamine, diethanolamine were admixed in M25 grade concrete and studied for their impact on the strength and corrosion inhibiting properties of concrete. From the experimental test results, the following conclusions can be drawn.

1. Optimum dosage of corrosion inhibitor admixture will enhance the integrity and uniformity of concrete.

2. For M25 grade concrete the optimum percentages of corrosion inhibitor admixture was found to be $4 \%$ for Calcium Nitrite, $3 \%$ for Sodium Nitrite, $2 \%$ for Hexamine and 3\% for Di-ethanolamine.

3. Calcium Nitrite corrosion inhibitor admixture imparts increased compressive, split- tensile and flexural strength than other corrosion inhibitors at 28 days.

4. All the corrosion inhibitors used in the study have enhanced the compressive strength, split tensile strength, and flexural strength of concrete.

5. Calcium nitrite in concrete has proved superior in enhancing the compressive strength and similar observations are made in split-tensile and flexural strength of calcium nitrite admixed concrete mixes. This is may be due to presence of calcium ions and formation of insoluble $\mathrm{C}-\mathrm{H}$ bonds. Calcium nitrite corrosion inhibitor forms shielding hydrophobic film on the rebar surface in high alkalinity concrete environment by adsorbing the ions of inhibitors on to the surface which eventually delays the rate of corrosion by obstructive cathodic /or anodic reactions.

\section{References}

1. Diagnosis and Assessment of Concrete StructuresState of the Art Report; CEB Bulletin d'information N. 192; International Federation for Structural Concrete (FIB): Lausanne, Switzerland, January 1989.

2. R Polder, C Andrade, B Elsener, J Gulikers, R Weidert, M Raupach, 'Recommendations of RILEM TC 154-EMC: Electrochemical techniques for measuring metallic corrosion. Test method for on-site measurement of resistivity of concrete. Mater. Struct. 2003, 36, 461-471

3. Sateesh, N., Sampath Rao, P., Ravishanker, D.V., Satyanarayana, K (2015). 'Effect of Moisture on GFRP Composite Materials (2015) Materials Today: Proceedings, 2 (4-5), pp. 2902-2908

4. V Srinivasa Reddy, M V Seshagiri Rao, S Shrihari," Appraisal of Processing Techniques for Recycled Aggregates in Concrete", International Journal of Engineering and Advanced Technology (IJEAT) ISSN: 2249 - 8958, Volume-8 Issue-6, August 2019, Retrieval Number F8407088619/2019@BEIESP, DOI: 10.35940/ijeat.F8407.088619, pp.1661-1665

5. Devi, G.N., Saranya, J., Manjubaashini, N., Thangadurai, T.D., Roopan, S.M., Chitra, S (2017), 'Polyamidoaminoepichlorohydrin resin a novel synthetic anti-corrosive water soluble polymer for mild steel', Progress in Organic Coatings, 109, pp. 117-125. 
6. M Finsgar, J Jackson (2014), 'Application of corrosion inhibitors for steels in acidic media for the oil and gas industry: a review', Corrosion Science, vol. 86, pp. 1741.

7. M Hayyan, SA Sameh, A Hayyan, IM AlNashef (2012), 'Utilizing of sodium nitrite as inhibitor for protection of carbon steel in salt solution', International Journal of Electrochemical Science, vol. 7, no. 8, pp. 6941-6950.

8. Torres-Acosta, Martinez (2012), 'State of the Art on Cactus Additions in Alkaline Media as Corrosion Inhibitors' ,Hindawi Publishing Corporation ,international Journal of Corrosion, vol. 2, pp. 641650

9. Tummala Suresh Kumar, Kosaraju Satyanarayana, Materials Today: Proceeding, 26 (2), 3228-3233, (2020)

10. JS Reou, JS, KY Ann (2008), 'The electrochemical assessment of corrosion inhibition effect of calcium nitrite in blended concretes', Materials Chemistry and Physics, vol. 109, no. 2, pp. 526- 533.

11. KY Ann, HS Jung, HS Kim, SS Kim, HY Moon (2006), 'Effect of Calcium nitrite-based corrosion inhibitor in preventing corrosion of embedded steel in concrete', Cement Concrete Res., vol. 36, pp. 530- 535 